\title{
Semi-natural habitats in boreal Europe: a rise of a social-ecological research agenda
}

\author{
$\underline{\text { Irina Herzon }}_{\text {Rašomavičius }^{1,2}}^{10}, \underline{\text { Kaisa J. Raatikainen }}^{3,4}, \underline{\text { Solvi Wehn }}^{5,6}, \underline{\text { Solvita Rūsina }}^{7}, \underline{\text { Aveliina Helm }}^{8}, \underline{\text { Sara A. O. Cousins }}^{9}$ and $^{\text {Valerijus }}$
}

\begin{abstract}
The European continent contains substantial areas of semi-natural habitats, mostly grasslands, which are among the most endangered habitats in Europe. Their continued existence depends on some form of human activity, for either production or conservation purposes, or both. We examined the share of semi-natural grasslands within the general grassland areas in boreal Europe. We reviewed research literature across the region to compile evidence on semi-natural grasslands and other semi-natural habitats, such as wooded pastures, in respect to a range of topics such as ecology, land-use change, socioeconomics, and production. We also explored drivers of the research agenda and outlined future research needs. Challenges are faced when defining and quantifying semi-natural habitats even across a restricted region. Agricultural development and other policies clearly impact the research agenda in various countries. There are recent signs of a shift from classical ecological studies toward more multidisciplinary and integrated research. To sufficiently address the threats faced by semi-natural habitats, political and research frameworks in the European Union should pay more attention to the social-ecological complexity inherent in their management and should support the engagement of various actors into participatory governance processes. This is in line with a full-farm approach implicit in high nature value farming systems.
\end{abstract}

Key Words: agriculture; biodiversity; farmland; social-ecological systems; trends

\section{INTRODUCTION}

The European continent holds substantial areas of so-called seminatural habitats. These were established on cleared woodland, shrublands, drained marshland, or natural grasslands, through centuries of pastoral activities (as explained by, e.g., Hopkins 2009, Veen et al. 2009, Peeters 2015). Communities on such habitats have evolved under both natural processes, such as spontaneous colonization by species, and traditional agricultural activities. Such communities are mostly dependent on the continuation of human activities to prevent succession toward scrub and woodland. This traditional management includes grazing, mowing, burning, and the removal of trees and shrubs, but precludes ploughing, substantial fertilizing, liming, drainage, or herbicide use (Norderhaug and Johansen 2011, Peeters et al. 2014). Some of the semi-natural habitats, e.g., sylvo- or ligneous pastures, burned and/or grazed heaths, mowed or grazed mires and fens, are characterized by a relatively high cover of shrubs and/or trees or a predominant cover of non-gramineous species (e.g., Plieninger et al. 2015). The semi-natural habitats are a key source of forage in so-called high nature value (HNV) farming systems (Keenleyside et al. 2014). The HNV farmland, with seminatural habitats embedded in it to various extent, may represent as much as $30 \%$ of the agricultural land in the European Union (EU; Lomba et al. 2014).

Most of the semi-natural habitats are grasslands, that is, areas with at least $10 \%$ vascular vegetation cover, dominated or codominated by graminoid and forb growth forms, and where the trees form a single-layer canopy providing less than $10 \%$ cover and reaching less than $5 \mathrm{~m}$ in height (Dixon et al. 2014). These grasslands are characterized by high levels of biodiversity because of moderate human disturbance over thousands of years and the major influence of environmental factors over their species composition and ecological dynamics (Squires et al. 2017, Auffret and Cousins 2018). Grasslands have exceptional small-scale plant diversity (Wilson et al. 2012), a previously high share of indigenous and endemic species (e.g., Bruchmann and Hobohm 2010), and a large fraction of red-listed species (Eriksson and Cousins 2014). This biodiversity of plants, invertebrates, and fungi among other organisms is also highly threatened across Europe (Dengler et al. 2014, Plieninger et al. 2015, Janssen et al. 2016). Their cover can be approximated as a "rough grazing" class reported in the Farm Structure Survey, which makes about 30\% of the total permanent grassland cover (EUROSTAT 2013).

Other ecologically valuable grasslands in Europe, natural grasslands, which are maintained almost entirely by environmental conditions and wild herbivore grazing such as former steppe and flood meadows, have been converted in temperate regions into crop fields or are managed as production grasslands (Dixon et al. 2014, Squires et al. 2017). True natural grasslands play no role in production and remain extant mainly in the Arctic and Alpine regions, as well as along the coasts, where they escaped the agricultural conversion (Emanuelsson 2009, Squires et al. 2017). Such areas are reservoirs of intact grassland communities, which are among the most endangered habitat types globally (Newbold et al. 2016).

Apart from semi-natural, permanent grasslands in the EU include the "permanent pasture and meadow" class, that is, agriculturally improved grassland for growing herbaceous forage crops and not included in the crop rotation scheme of an agricultural holding. Such grasslands covers over half of all permanent grassland (EUROSTAT 2013). As a result of fertilization, re-seeding, and intensive grazing, they have relatively species-poor swards and

${ }^{1}$ Department of Agricultural Sciences, University of Helsinki, ${ }^{2}$ Helsinki Institute of Sustainability Science HELSUS, ${ }^{3}$ University of Jyväskylä, Department of Biological and Environmental Science, School of Resource Wisdom, University of Jyvaskyla, Finland, ${ }^{4}$ University of Turku, Department of Geography and Geology, Geography Section, Turku, Finland, ${ }^{5}$ NIBIO - Norwegian institute of Bioeconomy Research, Stjørdal, Norway, ${ }^{6}$ Multiconsult, Trondheim, Norway, ${ }^{7}$ Department of Geography, Faculty of Geography and Earth Sciences, University of Latvia, Riga, Latvia, ${ }^{8}$ Institute of Ecology and Earth Sciences, University of Tartu, Tartu, Estonia, ${ }^{9}$ Stockholm University, Department of Physical Geography,

${ }^{10}$ Nature Research Centre, Institute of Botany, Vilnius, Lithuania 
associated biodiversity (Bullock et al. 2020). Finally, about $2 \%$ of the permanent grassland are not used for production on a shortor long-term basis, but are not yet overgrown. Their ecological values may vary considerably but such abandoned areas comprise a pool of grasslands that can potentially be restored into the seminatural state (Török et al. 2018), or converted to other land uses. Permanent grasslands predominate in most EU countries, except in Scandinavia and Finland, where grasslands are re-seeded at even shorter than five-year intervals and rotated with crops. In such countries, grassland production may be of limited value for semi-natural grassland species (Bullock et al. 2020, Tiainen et al. 2020).

Considerable declines have occurred in the production role of semi-natural vegetation across HNV farming systems because of a tendency to intensify management on parts of the farmland (including conversion of semi-natural land into cultivated grasslands or arable crops) and abandonment on others. Apart from production and biodiversity conservation, semi-natural habitats are increasingly valued for other public goods such as carbon sequestration, water retention, cultural heritage, reduced fire risks, and conservation of local livestock breeds (Lindborg et al. 2008, Veen et al. 2009, García-Feced et al. 2015, Peeters 2015, Plieninger et al. 2015, Janssen et al. 2016, Wehn et al. 2018a, Bengtsson et al. 2019).

Regardless of the main management purpose (production of marketable or public goods), semi-natural habitats depend on active management by certain societal actors, and can therefore be defined as social-ecological systems (Raatikainen and Barron 2017, Torralba et al. 2018). Ensuring the existence of such systems into the future requires understanding their place within a farm or landscape system and the diverse aspects pertaining to production regime, economics, public perceptions, cultural values, and ecology.

In this review, we focus on the European boreal region, i.e., Norway, Sweden, Finland, Estonia, Latvia, and Lithuania, with the aim of understanding what types of evidence and what gaps exist regarding the semi-natural habitats and how important seminatural grasslands are within an overall pool of agricultural land in the region. In the latter, we target only grasslands because the land use statistics are available only for them. Our specific objectives are the following:

1. Examining the current status of semi-natural grasslands within the overall grassland cover of the region,

2. Quantifying how research attention in the literature toward aspects relevant to semi-natural habitats has developed over time and across the region,

3. Explore drivers of the research agenda within the region and among countries,

4. Outline future research directions to address gaps and needs for further evidence.

We collected agricultural statistics, conducted a literature review, and analyzed the research papers according to their focus. The land use statistics are available only for grasslands. In the literature review, we included all types of semi-natural habitats, including those not classified as grassland in sensu stricto. The decision to limit the review to one region, albeit large, was dictated by biogeographic similarities among the countries and historical patterns of land use in the region. On the other hand, the countries differ in some trajectories of socioeconomic development.

\section{METHODS}

\section{Defining the focus}

The boreal region is located in the Northern Hemisphere with a subarctic climate. In Europe, the boreal biogeographical region includes parts of Norway, Sweden, Finland, Estonia, Latvia, Lithuania, Belarus, and the Russian Federation (EEA 2002), with a subarctic continental climate in the northern part and a temperate humid continental climate in the southern part of the region. We excluded Belarus and the Russian Federation from this review because of their unique political context and marginal areas falling within the boreal region. From now on, we will refer to Estonia, Latvia, and Lithuania as the Baltic countries, whenever treating them as one region of a similar socioeconomic history before they joined the EU in 2004. We will refer to Norway, Sweden, and Finland as the Nordic countries, considering their shared market-economy context.

Each country has somewhat different ways of defining seminatural habitats. We refined our choice of search words used in the review according to these definitions. Apart from areas directly used for agriculture, small elements in the agricultural landscape that are non-cropped and not utilized for grass production, such as hedgerows, road verges, buffer strips, midfield islets, ditches, field margins, or woodlots, are often referred to as semi-natural habitats (García-Feced et al. 2015). However, we excluded these elements from this work, unless they were studied together with semi-natural habitats, e.g., as complementary habitats. We also excluded the reindeer grazing systems in Norway, Sweden, and Finland, because such pastoral systems are not regarded as agricultural land use.

\section{Data on grassland use}

To understand how semi-natural grasslands are currently used in regional grassland-based production, we retrieved data from national land use registers and evaluations (Table A1.1). For comparability between the EU countries and Norway, we derived data on the permanent grasslands in Norway from EUROSTAT because the same definition for permanent grassland, i.e., a minimum of five consecutive years in one place, was applied during this period. The land use class terminology in official registers recognizes permanent grasslands as land used to grow grasses or other forage that has not been included in the crop rotation during the past five or more years, including land that can be grazed and that forms part of established local land use practices (EU 2013). The remaining grassland in production is reported as "Temporary grasses." The semi-natural grasslands are mostly categorized as permanent grassland as long as they receive subsidies as agricultural areas. We retrieved the seminatural grassland areas from the latest national evaluations. We only used utilized grassland area for permanent and temporary grasslands, and also summarized the best estimates of unmanaged areas for semi-natural grasslands.

\section{Literature review}

To understand how research on semi-natural habitats developed with time and across the region, we conducted a literature review based on two searches: one in Scopus on 24 April 2018 and the 
other in Web of Science on 13 July 2018. The searches were limited to journal articles and reviews published in English. We listed international and country-specific terms used in relation to the semi-natural habitats and searched for their occurrence in the title, abstract, or keywords list (in Scopus) or in the topic (Web of Science). The key search terms were: alvar*, hay, meadow*, grassland*, heath*, forest pasture*, grazed forest*, grazed woodland*, wooded pasture*, wood-pastur*, traditional rural biotope*, and cultural landscape. All of these had to be accompanied with one of the following descriptors: seminatural*, seminatural*, semi natural, high-nature-value, high nature value, extensive livestock production, rough grazing, silvopastur*, silvo-pastur*, transhumance, or summer farming. We also limited the search to the focus region: Finland, Estonia, Latvia, Lithuania, Sweden, Norway, or *boreal Europe.

\section{Data analysis}

We categorized the selected papers into several research aspects, which we considered most relevant for semi-natural grasslands. The aspects were, (1) ecological (with two sub-types [A] community level such as field survey, evaluation, monitoring, and sub-type [B] autecological or single-species studies), (2) agronomic (production, biomass quantity and quality, animal welfare, animal growth), (3) cultural ecosystem services (cultural values, traditional land use, heritage, landscape management, local production, artisanal products), (4) socioeconomic (profitability, motivations, challenges, opportunities, solutions), (5) political (subsidies, regulations), (6) functioning and regulating ecosystem services (pollination, flood management, soil, fire, etc.), (7) land use change, (8) techniques (for management or detection), (9) innovative land use solutions (bioenergy, education, novel tourism, etc.), and (10) restoration (introduction of management). We assigned one to three aspects to each paper by paying attention to the research focus and objectives of the paper. We excluded papers focused exclusively on the pre-historic development of grassland-dominated landscapes. Aspect categorization was conducted based on us reading the abstracts of each paper and, if this proved insufficient, also reading the full publication texts.

Out of the 1009 papers returned by the searches, we selected 20 random papers as a training set for independent classification by six co-authors. We screened the papers for relevance (yes or no) and the above-listed aspects. After this, we compared the results and clarified reasons for divergent decisions, and refined the aspects and classification rules. Finally, we divided all the papers among the same six authors, who proceeded with classifying them. For additional consistency checks, the six authors divided into pairs. Of all the papers screened by both authors in a pair, five were checked by both authors to create an overlap in paper classification.

We mainly applied descriptive statistics to both data sets concerning land use and derived from the classification of the literature. We analyzed the literature data set according to paper origin, year of publication, and the main aspects and their combinations (whether the papers covered one, two, or three aspects, thus taking a more interdisciplinary approach). For analyzing the data according to country, we created duplicates for publications covering more than one country, and thus studies conducted, e.g., in both Sweden and Estonia were assigned to both countries. The mean publication year for the papers of each aspect indicates the peak period of research activity for each respective aspect.

\section{RESULTS}

\section{Defining semi-natural habitats across the region}

The practices of defining semi-natural habitats along with assigning them to the land use classes in the national registers differed among the countries. For example, wooded meadows are mostly regarded as grasslands and included into the permanent grassland land use class, except in Finland and, when not under management, in Estonia. Norway has a classification of its own. Each of its three nature types, i.e., natural, semi-natural, and artificial sites, includes habitats that could be regarded as seminatural (Artsdatabanken 2018). Furthermore, old arable fields fallowed for decades or severely overgrown permanent cultivated grasslands are regarded as semi-natural grasslands under certain country-specific criteria. In Latvia, previously cultivated permanent grasslands are considered semi-natural if they contain a certain number and abundance of plant indicator species, while a lack of ploughing history is the decisive factor in Estonia. In Lithuania, the evaluation is based on plant community composition. In the Nordic countries, semi-natural grasslands are defined through a long continuity of management and additionally as areas that have not been sown, ploughed, or fertilized.

Existing management further determines the land use class: permanent grassland only includes semi-natural grasslands receiving agricultural subsidies, while, as a habitat, they also exist outside subsidized areas and some are managed. No consistent data exist on how much of the semi-natural grasslands, especially non-grassland semi-natural habitats, are still ecologically (i.e., retain their communities) available, but are currently not in production or managed.

\section{Semi-natural grasslands within the overall use of grasslands}

Estonia and Sweden have the highest proportion of semi-natural grassland in relation to total grassland cover (approximately $20 \%$ ). Finland has the lowest relative area for permanent and semi-natural grasslands of all grassland cover (approximately $3 \%$ ). The share of the temporary (or rotational leys) grassland within the grasslands in each country is particularly contrasting between two Nordic EU countries (Finland and Sweden) and the others (Fig. 1, Table A1.1). The rotational grassland share is 70 $90 \%$ in the former, while the others contain over $60 \%$ of permanent grassland cover, as defined by the regulation that grassland cover should remain in one place for a minimum of five consecutive years.

\section{Research inquiry into the semi-natural habitats}

Of 1009 papers identified in the literature search, 561 were relevant to our research topic and we classified them further. Nearly all reviewed papers focused on only one country. Five studies spanned two or three countries of the region. Nearly half of the relevant studies (43\%) were from Sweden, $18 \%$ from Norway, 17\% from Finland, 15\% from Estonia, 3\% from Lithuania, and 1\% from Latvia (Fig. 2). Finally, 13 research papers $(2 \%)$ covered the whole region: these were review or metaanalysis papers, and they were mostly pan-European with examples from our region. 
Fig. 1. Relative areas for three grassland types: permanent (excluding semi-natural grassland), semi-natural, and temporary (rotational, five or less years on one field parcel) grasslands in the boreal countries of northern Europe. Only areas that are managed either for production or as part of agricultural policy requirements are included.

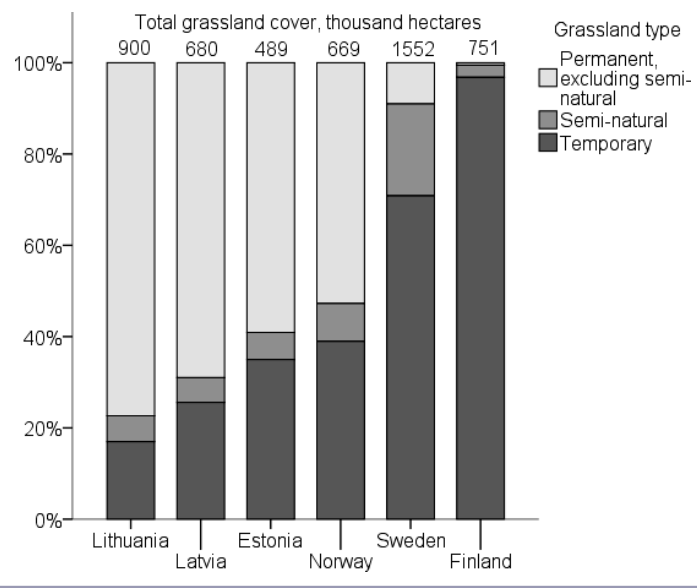

Fig. 2. Map of the study region, showing the division into Nordic and Baltic countries and the number of reviewed articles per country (in parentheses). Country names are abbreviated as follows: NOR: Norway, SWE: Sweden, FIN: Finland, EST: Estonia, LVA: Latvia, and LTU: Lithuania. Administrative units from the European Commission, Eurostats, 2016. https:/lec. europa.eu/eurostat/web/gisco/geodata/referencedata/administrative-units-statistical-units/ countries\#countries 16

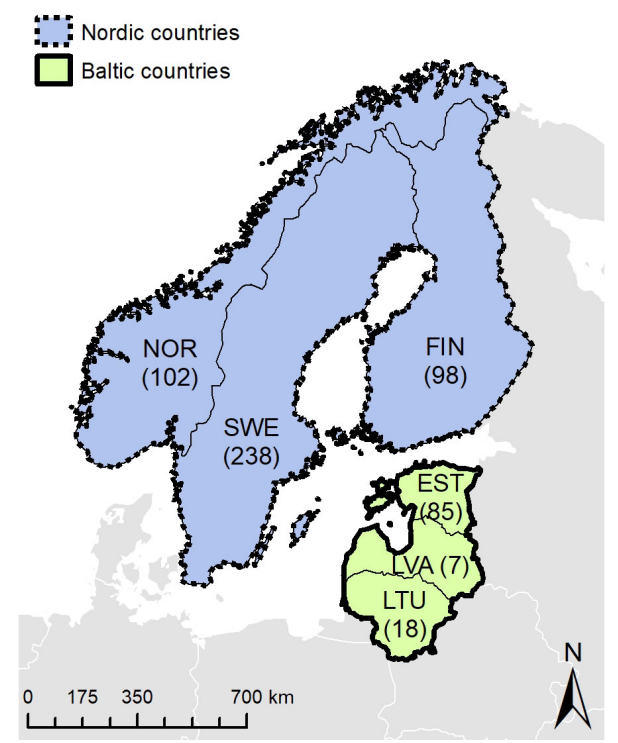

We assigned two research aspects to 232 papers (41\%), three aspects to 55 papers $(10 \%)$, and one aspect to the rest $(49 \%)$. The reviewed research most frequently focused on ecological aspects (43\% community ecology and $8 \%$ autecology), followed by management techniques, or detection of the semi-natural habitats (15\%; called Management from now on) and on land use change (14\%; Fig. 3). Innovative solutions for using semi-natural habitats $(1 \%)$, ecosystem service provision, and socioeconomics and production $(2-3 \%)$ were the least represented research aspects. Because of low occurrence, we pooled the aspects most strongly related to socioeconomic dimensions (socioeconomics, policy, cultural ecosystem services) into the Socioeconomics variable.

Fig. 3. Research aspects identified in 562 papers relevant for semi-natural habitats in boreal Europe, with the number of publications for each aspect given in the white text box. Papers were assigned one to three aspects, and therefore the number of aspects exceeds the total number of publications.

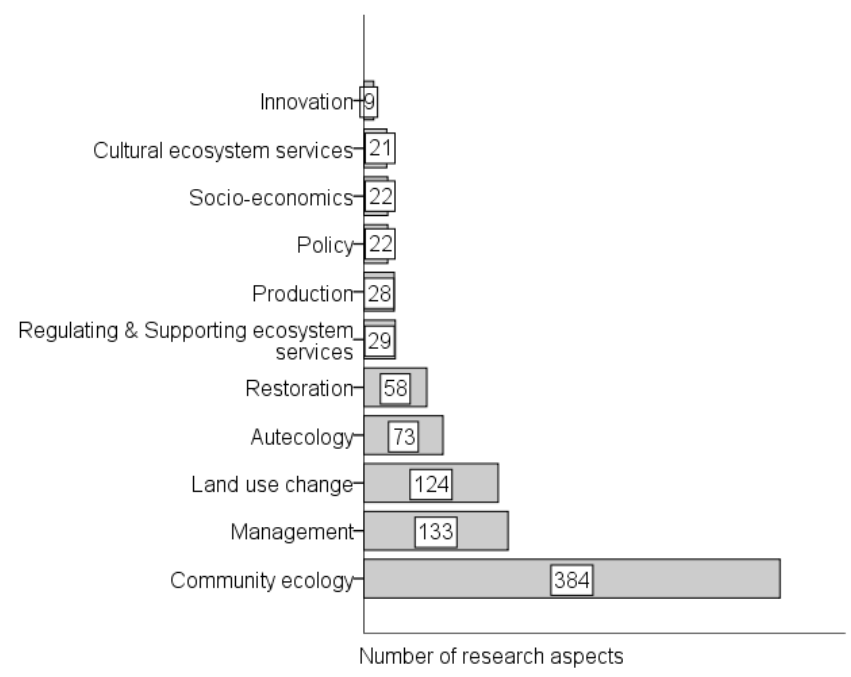

Research inquiry into semi-natural habitats intensified in the early 2000s (Fig. 4). Two research aspects have been predominant throughout the whole period: community ecology and land use change. These were nearly the only focus areas prior to 1996. Since 1996, management and restoration are two other systematically and frequently researched themes, whereas studies on production aspects remain infrequent. After 2000, the number of publications increased and the research focus diversified into aspects pertaining to socioeconomic dimensions (including policy and cultural ecosystem services) and regulating and supporting ecosystem services. Autecological studies mostly dealt with population dynamics of one or a few focal species specialized in semi-natural habitats, questions of species habitat requirements, their distribution modeling, land use effects, and species population genetics or evolutionary ecology. The innovative ways of using semi-natural habitats is the most recent line of research. The average publication year for most of the aspects was 2007, while average publication year for socioeconomic dimensions and innovations was as recent as 2012 and 2013, respectively (Fig. 4).

In Sweden and Norway, research on semi-natural habitats has been continuous throughout the examined period beginning 
Fig. 4. The time line of the research aspects as they appear in the research literature concerning semi-natural habitats in the boreal region. Because of small values and for clarity, the socioeconomic aspects (socioeconomics, policy, cultural ecosystem services) are pooled as Socioeconomics. The mean publication year indicates the peak publication period for each aspect. Note that the panels differ in the $\mathrm{x}$ - and $\mathrm{y}$-axis scales.
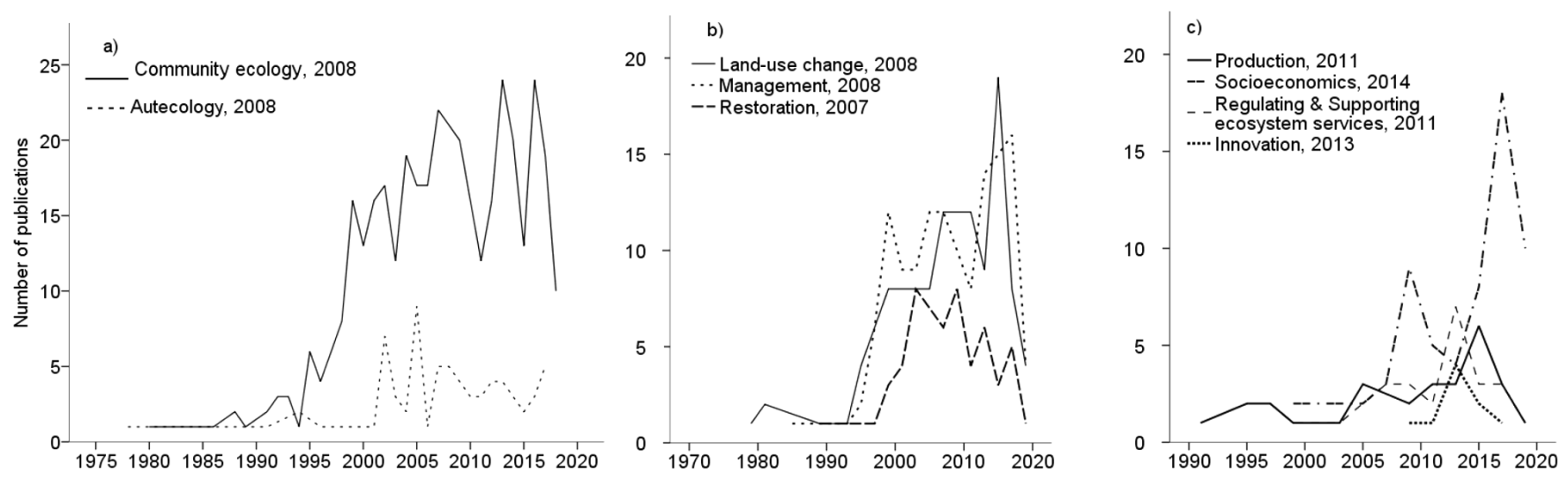

around 1970-1980, albeit first at low levels (Fig. 5). In Finland and Estonia, research became established in the early 1990s and as late as the 2000s in the other Baltic countries. Having the highest overall number of studies, Sweden leads the share of publications concerning socioeconomics, regulating and supporting ecosystem services, land use change, management (circa $40 \%$ of the studies), and, together with Finland, restoration. Estonia and Norway lead the research on innovative use of semi-natural habitats $(30 \%)$. Cross-national publications are fairly recent, as is peer-reviewed research from Latvia and Lithuania.

Fig. 5. Research time line according to country concerning semi-natural habitats by publication decade.

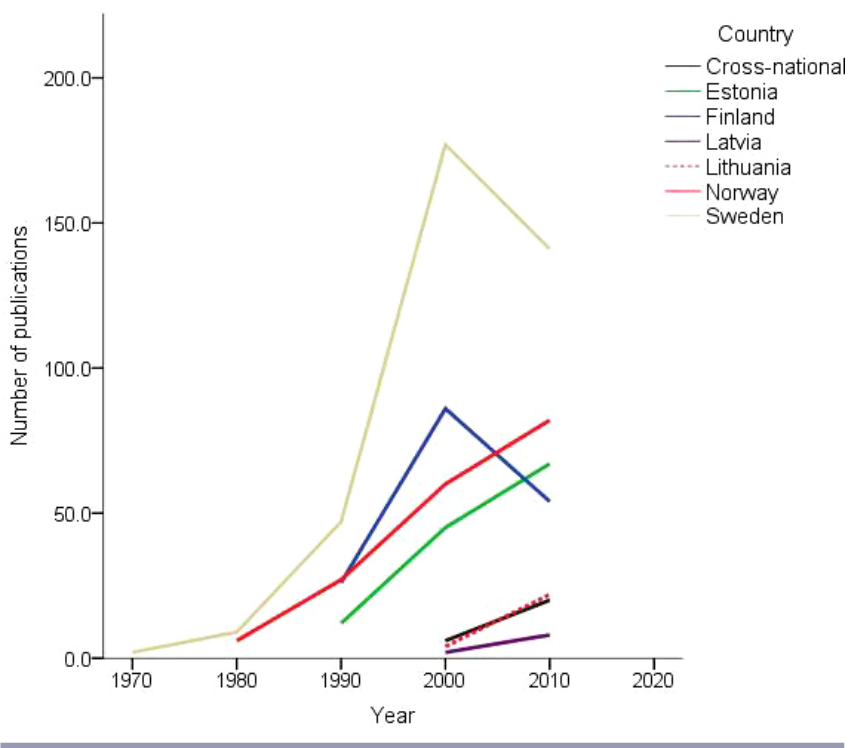

The research arena in each country is dominated by studies on ecological aspects (40-70\%; Fig. 6a). Land use change is the only other crosscutting aspect among the countries. All aspects are addressed in Finland, Estonia, and Norway. Latvia has the least diverse research agenda, with the lowest number of publications. Latvian research gaps include production, socioeconomics, management, restoration, and innovation aspects. Cross-national research attention is strong in socioeconomics (includes policy and cultural ecosystem services), land use change, and regulatory or supporting ecosystem services. We found a contrast in the relative representation of research with the production aspect: of all the research papers that included it, $\sim 60 \%$ were from Norway, followed by Sweden (15\%; Fig. 6b). The remaining countries together produced less than $20 \%$ of the papers regarding this aspect, or it was non-existent in certain countries. Production studies are not numerous in Lithuania, but they are common in relation to other aspects.

Studies focusing on one research aspect $(30 \%$ of the reviewed literature) and studies combining two aspects (51\%) have been published throughout the entire time line, but studies including at least three aspects $(18 \%)$ became common in the early $2000 \mathrm{~s}$. Ecology, management and detection techniques, land use change, and restoration are the aspects combined most frequently. Research into socioeconomic aspects is most frequently combined with management. Production aspects are variably combined with socioeconomics, cultural ecosystem services, management, other ecosystem services, and innovation.

\section{DISCUSSION}

\section{Semi-natural grasslands: from agricultural land to conservation sites}

Grassland-based production in the boreal region, with ruminant livestock, is the backbone of agricultural land use because of unfavorable climatic and topographic conditions for arable crops. However, when attempting to understand how semi-natural grasslands fit the overall grassland management across the boreal region, we faced two challenges. First, there are partially contradictory definitions for semi-natural grasslands (and, more broadly, for semi-natural habitats) due to varied traditions in each country. Estonia implements the strictest definition among the Baltic countries focusing on the grassland sites that have no known history of ploughing or fertilization because of relatively 
Fig. 6. The relative representation (\%) of the research aspects of semi-natural habitats (a) within each country and (b) among the countries in the boreal region. Cross-national stands for the region overall, including Europe-wide studies. The number after a country name denotes the number of publications.
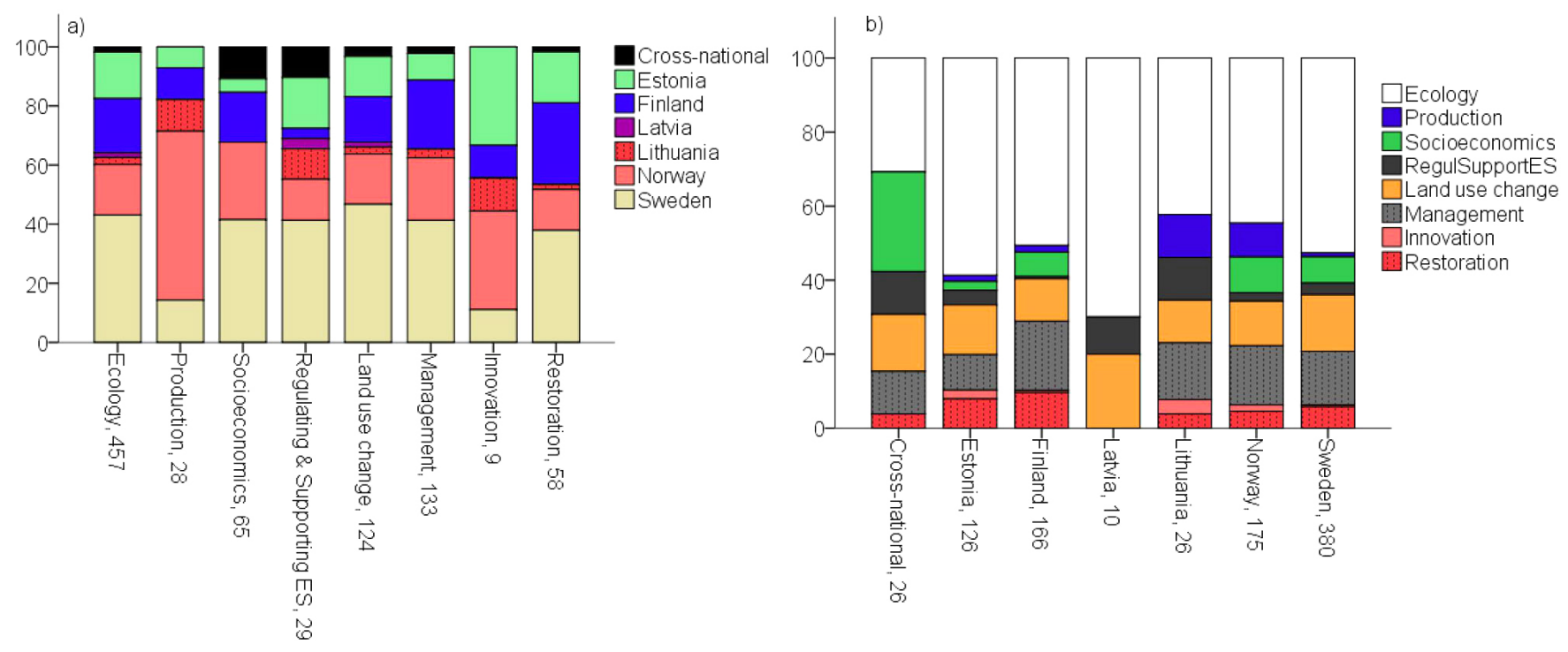

good coverage of remaining historical grasslands. Given the small area and high fragmentation of semi-natural grasslands in Latvia and Lithuania, national experts decided on a relatively low baseline for recognizing semi-natural grassland as EU conservation habitats. Thus, different starting points in seminatural grassland area and condition at the beginning of the 20th century led to inconsistent definition criteria. Also cultural discourses have affected the way semi-natural habitats have been considered in nature conservation. Common to the Baltic countries and Finland, a legacy of strongly separating conservation and agricultural land use explains a non-existing discourse on semi-naturalness as an idea for nature conservation. In Finland, semi-natural grasslands' values for conservation received recognition only in the late 1990s, as entering the EU led to an adoption of a less dualistic approach to nature conservation (Vuorisalo and Laihonen 2000). The Nordic countries' definitions further highlight the cultural heritage of semi-natural grasslands, a long continuity of traditional grassland management without arable rotation.

Second, collecting comparable data was problematic because national land use reporting is not based on vegetation characteristics or land use type, but rather on the current political framing of what constitutes "agricultural land" or "permanent grassland." The national statistics base their numbers on land that receives subsidies, although semi-natural vegetation also exists outside of subsidized land. Thus, comparable data on seminatural habitat area not classified as grassland (grazed forests, heaths, fens, and mires) do not exist; they do not receive subsidies, even under management. Their national area varies manyfold: from 4000 hectares encompassing all different types in Lithuania to 60,000 hectares of coastal heath and 4 million hectares of grazed forest alone in Norway. The classification of woody seminatural habitats also varies notably: for example, wood pastures can be included in "permanent grassland" in Estonia and Sweden, even if the tree cover exceeds $10 \%$, but this is not the case in Finland. Therefore, the observed pattern with semi-natural grassland use is indicative rather than exact. It also elucidates the importance of typology comparable among the countries. The current ambiguity in both terminology and statistics makes information on extent, ecological quality, or management status of these threatened habitat types inexact and effective targeting of conservation actions extremely difficult (Raatikainen et al. 2017).

No consistent data are available concerning the shares of managed semi-natural grassland in relation to overall grassland cover in the Baltic and Nordic countries. Though considerably larger areas of semi-natural grassland are reported from the former socialist countries compared to Western European countries (e.g., Sutcliffe et al. 2015), this may not be reflected in the quantity of grassland still under management. Because of high levels of abandonment of marginally productive grasslands in all countries, these areas lose their status of agricultural land and disappear from the land registers. For example, only 29,221 hectares of semi-natural grasslands are reported as managed in Estonia (based on subsidies), while the Natura 2000 Habitats Directive registry lists 132,000 hectares of semi-natural grassland. In Latvia, the share of abandoned semi-natural grasslands is $40 \%$ (Rūsina 2017). In Norway, only $67 \%$ of the coastal heathlands are reported as unaffected by shrub and tree regrowth (Johansen et al. 2015). An expert estimate for Finland raises the proportion of unmanaged area as high as $80 \%$ of all semi-natural habitats (Raatikainen et al. 2017).

The clearest contrast in grassland use between the two regions is the shares of permanent and temporary grasslands. Although appreciative shares of grasslands are managed as permanent (over $50 \%$ of the total grassland area) in the Baltic countries, most are agriculturally improved. The current criterion for grassland 
"permanence" specifies that rotational grassland must remain in one place for only five years, and thus their ecological values may remain low. We found large differences in the shares of grassland uses among the Nordic countries. Most production of silage and hay in Finland and Sweden comes from high-input rotational grasslands, i.e., leys (re-seeded at intervals of 3-5 years and included in crop rotations). Strong national public policies (also before the EU) heavily subsidized the process of intensification of grassland-based production in these countries (Eriksson and Cousins 2014). Such grasslands have low ecological values compared to the other grassland types, and their restoration into species-rich communities may require decades of dedicated management (Bullock et al. 2020). In Norway, a relatively high share of permanent grasslands exists because of the country's topography. Despite country-specific differences, in all countries, remaining areas of semi-natural grassland are estimated to be only a few percent as compared to the beginning of the 20th century (Luoto et al. 2003, Eriksson and Cousins 2014, EEA 2016).

Minor shares of semi-natural grasslands and other habitats across the region plausibly reflect their currently marginal production role. Large areas (10-30\% of permanent grasslands in the Baltic countries) are reported as managed only because of public subsidies (EUROSTAT 2013). However, to substantiate this claim we need much better data, also on actual fodder production volumes and farm economics. These habitat types, formerly crucial for rural livelihoods, would ecologically have been all but lost without dedicated public support for their maintenance for conservation such as the Norwegian Action Plan for Hay Meadows (Norwegian Environment Agency 2009), the agrienvironment support for semi-natural grasslands, and conservation funding for managing other semi-natural habitats.

\section{Policy drives the research agenda}

Research on semi-natural habitats substantially increased in the late 1990s across the whole region, and especially in the Nordic countries. The most plausible reason is the Convention on Biological Diversity ratification in 1993, which in turn led to greater integration of biodiversity objectives into national and EU conservation and Common Agricultural Policy (CAP). The EU Habitat Directive recognizes semi-natural habitat types as habitats of European Importance in conservation (Halada et al. 2011) and obligates Member States to map, describe, and protect these habitats. Sweden and Finland became members of the EU in 1995 and the Baltic countries in 2004, and began implementing common EU legislation at time of entry. Meeting the accession requirements seemed to spark research in the Baltic countries after 2000. At accession, the countries also began paying special (agrienvironment or, presently, agri-climate-environment) payments to managers of the most valuable semi-natural habitats to ensure their continuous management for conservation, with or without associated production. Thus, public funding for biodiversity management opened opportunities for applied research on seminatural habitats. Such research typically focuses on the impacts of management practices on species communities, mostly species diversity (cf. Benedetti 2017). Studies on population genetics or genetic diversity are rare but might increase as cost of genetic analyses decreases (Plue et al. 2019).

Norway presents a unique case of a market economy country outside of the EU and CAP. Its agriculture, however, is just as highly regulated as that in the EU (Kvakkestad et al. 2015). Since the late 1990s, national policies have focused on maintaining rural viability, with an emphasis on the positive links between food production and other public goods such as biodiversity and food quality (Ministry of Agriculture 1999). This supports research focused on production values of semi-natural habitats. In response to the Convention on Biological Diversity and the EU Habitat Directive, Norway introduced the Nature Diversity Act in 2009, which gave high conservation priority to semi-natural habitats (Ministry of the Environment 2009), thus creating a political framing similar to that of the EU.

Sweden holds the leading position in research and conservation policies concerning semi-natural habitats. It has had the broadest research agenda and inspired research in other countries. For example, it has led the advanced understanding on how historical land use has affected the development of semi-natural habitats today (e.g., Pärtel et al. 1999, Eriksson et al. 2002, Cousins and Eriksson 2008, Olsson et al. 2011, Ödman and Olsson 2014, Cousins et al. 2015). The increasing knowledge on landscape history and the effect on present biodiversity in semi-natural habitats can assist developing approaches for alleviating negative side effects of rapid landscape and habitat changes in conservation (e.g., Eriksson et al. 2002, Kimberley et al. 2019). However, despite the prominence of research on semi-natural habitats in Sweden, it is too early to say to which degree these research results also drive the political agenda.

Influences of the EU and national policies on the research agenda are further reflected in expanding research into the socioeconomic aspects of management and restoration. Public payments made available under CAP and the Norwegian Action Plans stimulated research into farmers' acceptance of such public payments, their role in the farm economy, and best ways of targeting the payments (Lindborg et al. 2008, Birge and Herzon 2014, Kalda 2017, Raatikainen and Barron 2017, Wehn et al. 2018b). The abandonment of semi-natural habitats is a widespread phenomenon and, once special funding became available for restoration (e.g., agri-environmental non-productive investments), research intensified in all countries except Latvia. It is especially active in the Baltic countries (e.g., Vinogradovs et al. 2018).

Finally, the rise of a plethora of studies on ecosystems services (apart from production as a provisioning one) can also be attributed to policy processes (Millennium Ecosystem Assessment, the Aichi Biodiversity Targets, and IPBES). Pollination (e.g., Öckinger and Smith 2007, Jakobsson and Ågren 2014, Lundgren et al. 2016, Wehn et al. 2018a), soil functioning (Slepetiene et al. 2013), and cultural heritage (e.g., Raatikainen and Barron 2017, also Virret et al. 2019) are ecosystem services attributed to semi-natural habitats that have received the most attention in the region. Integrated planning tools to support ecosystem-based planning and sustainable grassland management are also explored (Villoslada et al. 2018).

Attention to production values of semi-natural habitats in most countries has been marginal or non-existent. The focus is mainly on potential quantity and quality of herbage from various grassland types for livestock use (e.g., Rosef and Bonesmo 2005, Bele et al. 2015, Moen et al. 2015, Skuodiene et al. 2016, Saastamoinen et al. 2017, Wehn et al. 2018a). Bele et al. (2018) took a perspective on Nordic low-intensity livestock systems raised on semi-natural grasslands as a case of localized 
sustainable agri-food systems, which allow "producers to combine production of food of documented high nutritional and gastronomic value with maintenance of biodiversity," (p. 1) thus being "a win-win recipe for both farmers and the society" (p. 1). Another framework of potential relevance is to integrate production from semi-natural grasslands with other ecosystem services (e.g., Virret et al. 2019). Such holistic assessments of multiple values would particularly benefit the HNV farming systems.

Norway leads research concerning production, giving due consideration to the conflict between extensive animal husbandry and predator conservation (e.g., Hansen et al. 2009, Mabille et al. 2015). It is also the only country in our study region that still has summer farming (e.g., Villa and Daugstad 2007, Daugstad et al. 2014). This practice concerns domestic animals transported away from main farmsteads to graze in enclosures and on commons near a summer farm (sater in Norwegian; fäbod in Swedish; Olsson et al. 2000, Lennartsson et al. 2018). In Sweden this practice ended in the beginning of the 20th century (Svensson 2018). In the Baltic Sea archipelago of Finland and Sweden, animals are transported between islands in grazing networks, often for conservation purposes (Mussaari et al. 2012, Plue et al. 2019). These practices, vestiges of the past, correspond to a more general tradition of transhumance (Liechti and Biber 2016). Marginal research effort into agricultural production from seminatural habitats reflects an evident neglect of them as forage sources, making their maintenance dependent on public subsidies.

Finding non-traditional ways of adding value to the management of semi-natural habitats is a recently arisen research theme. Examples of such non-traditional methods include recreation (most of the relevant studies come from Norway, e.g., Swensen 2008, Daugstad and Kirchengast 2013) and bioenergy (in Estonia and Latvia, Heinsoo et al. 2010, Melts et al. 2014, Hensgen et al. 2016). We found only nine studies incorporating such methods, which we classified as Innovation.

A described divide exists between Western Europe and Central and Eastern Europe in the research efforts to conserve farmland (Sutcliffe et al. 2015). This divide is nuanced in our data: only Lithuania and Latvia stand apart with particularly limited research. A reason may lead back to research "schools," i.e., whether anthropogenic grasslands have been considered an important conservation focus, with funding allocated to such research. Also, a considerable share of ecological research from Eastern European countries is published in non-English languages or regional journals, usually not detected in international reviews (compare to Sutcliffe et al. 2015). Finally, the efforts of a few field experts in two small countries are channeled into applied work for management and policy making without scientific publications. However, the example of Estonia, a small East European country, in bridging this divide is encouraging.

\section{Research into semi-natural habitats as social-ecological systems} Ecology is the oldest and predominant prism through which researchers look at semi-natural habitats: what species occur and where, and how do their populations fluctuate? What are the distribution and habitat requirements of rare species or areas with high diversity? How do various management regimes, or a lack of them, affect various taxa? These have been and remain the predominant research topics in all boreal countries and probably across the EU. A recent review on high nature value farming similarly reported that biodiversity and conservation is the key research inquiry in over $50 \%$ of publications, followed by the third on agricultural policy (Benedetti 2017). Ecological studies are often accompanied by other research perspectives: most papers classified as multi-aspect studies combine ecology, management, land use change, and restoration. These combinations have exposed the dependence of semi-natural habitats on human intervention, yet the interdisciplinary approach is still largely biophysical. Researchers have so far focused on describing structures and symptoms of the system, e.g., ecological effects of management practices or delays in species extinctions due to habitat loss. However, the survival of species and communities of semi-natural habitats is ultimately a socioeconomic problem, dependent on landowner acceptance, public recognition, and political will (Kumm 2003, 2004, Hartel and Plieninger 2014).

It is therefore appropriate to approach semi-natural habitats as social-ecological systems rather than as ecosystems. Habitat management, and the lack of it, lies at the heart of this emergent research focus: it has been the key topic linking various research aspects together. Social aspects of management, as part of farming and rural systems, is a fairly recent but expanding research theme. Management is the central linkage connecting the ecological and social subsystems to each other (Raatikainen and Barron 2017). Several studies demonstrated that traditional land use systems that created and maintained semi-natural habitats have been broken, and that social and ecological subsystems are decoupled as a result of agricultural modernization, globalization, and other large-scale changes that affect all Europe's rural areas (Fischer et al. 2012, Raatikainen and Barron 2017, Wehn et al. 2018b). These changes have proceeded at different paces in various regions, as our data on grassland use exemplify.

Yet many traditional farming landscapes with semi-natural habitats and high conservation value remain in Europe (Fischer et al. 2012). The concept and typologies of HNV farming systems could be a valuable framework for studying factors that enable the continuance of semi-natural habitats as part of viable farming systems (Lomba et al. 2019). The most recent research focus is on how to make HNV farming systems work at a new stage of societal development, through recoupling the linkages between people and nature in traditional farming landscapes along with modern landscapes with semi-natural remnants (Stenseke 2006, Lindborg et al. 2008, Fischer et al. 2012). Although farmers play a key role in this, engaging other actors in semi-natural habitat management is an important option (Kumm 2003, Raatikainen and Barron 2017). As Wehn et al. (2018b:259) observed, "without alternatives to management by farmers [semi-natural habitats] are likely to disappear in the next couple of decades ... long term conservation will require a means of addressing the continued decline of local farming communities".

Our results indicate a particularly strong role of policies in directing research agenda over the past 20 years, which emphasizes the role of governance as part of social-ecological research. Indeed, recent research has scrutinized the policies themselves, particularly agri-environmental payments, identifying 
at least three problems inherent to them. First, the agri-climateenvironment payment schemes reduce a holistic and placeembedded management of the semi-natural habitats into prescribed activities with supposedly predictable outcomes (Raatikainen and Barron 2017). This presents a stark contrast with the social-ecological systems approach that requires an acknowledgment of the multifunctionality and multiple values of the semi-natural habitats at the landscape level (Lindborg et al. 2008, Fischer et al. 2012). Second, public subsidies strongly emphasize financial rewards for specific practices over ecological (or social) results, thus further degrading cultural and economic values of semi-natural vegetation in the farm or rural business (Herzon et al. 2018). In Sweden, however, there are subsides to land managers to deliver ecological and cultural values with less focus on specific management practice. Third, the payment schemes typically target individual parcels, mainly those that are easy to manage and monitor, neglecting the need to increase ecological connectivity. The latter has been found important for species' viability and prevention of the ecological debt all across the region (e.g., Luoto et al. 2003, Helm et al. 2006, Cousins and Vanhoenacker 2011, Arponen et al. 2013, Takkis et al. 2013, Bommarco et al. 2014, Plue et al. 2019). Accumulating evidence of policy shortcomings in semi-natural habitat management has been a valuable outcome of research. Developing alternative approaches that work within and beyond existing policy tools is a matter of further research effort.

We also identified research gaps in the studied region (Box 1). These include disciplinary enquiries into ecological processes on the semi-natural habitats, technological advances, as well as interand transdisciplinary approaches. Deeper understanding of the social-ecological systems that are founded on grassland use for multiple benefits, including their unique and highly endangered conservation values, and recommendations for practice are needed for all Europe, and are relevant globally because grassland covers $\sim 40 \%$ of the Earth's surface (White et al. 2000).

Box 1: Specific challenges that, according to the reviewed literature, should be better addressed in the region through research and development.

Improving techniques for systematic inventories of semi-natural habitats and HNV farming systems, so that comparable data between countries and regions become available. These should make full use of remote sensing technologies and drones for monitoring.

Improving predictive modeling on the role of connectivity and past land use history on species distributions, along with species range shifts due to climate change as opposed to shifts caused by management.

Designing effective solutions for the targeted control of plant and animal species, including invasive species.

Improving and designing strategies for co-existence of top predators and livestock.

Adopting a landscape-level rather than a patch-level approach for targeting the interventions.

Designing and strengthening cooperative networks around seminatural habitat management, e.g., grazing networks, collaborative management of rural and urban inhabitants, involvement of other actors such as industry and retailers.

Operationalizing ecosystem services derived from semi-natural habitats as public goods going beyond production of biomass, such as pollination, biological control, carbon sequestration, water retention.

Developing and testing payment approaches, based on public and private funding, that reward the ecological state of semi-natural habitats rather than their management as such.

Developing and implementing multi-purpose land use planning approaches and participatory governance approaches.

Elaborating solutions for the continued decline of local farming communities in marginalized regions.

Development and testing of innovative institutional, regulatory, technical (including agronomy), and marketing solutions for revitalizing the use of semi-natural habitats within farms and other rural systems: ranging from alternative uses for biomass from semi-natural habitats to certification schemes for "meadow meat" and other products.

Quantifying the beneficial contributions of animal-based food production on semi-natural habitats, e.g., biodiversity maintenance, against negative impacts on resources, e.g., greenhouse gas emissions, using comprehensive life cycle analyses and other systemic approaches.

\section{CONCLUSION}

Our research related to semi-natural habitats demonstrated the role of the overall political framing in the EU and nationally for determining production and conservation values of semi-natural habitats, along with research directions and scope. Even across a restricted region with certain fruitful cross-border collaboration, we faced challenges in defining semi-natural grasslands in a consistent way and quantifying their area from land use registers. Overall, semi-natural grasslands and other habitats seem to hold a largely marginal role for current fodder production and farm economics in boreal Europe, though immensely important for biodiversity. However, we need more precise data on resource use and economics to substantiate this claim. We argue that it is time to shift the research focus from studying symptoms of seminatural habitat loss to studying treatment alternatives, that is, incorporating semi-natural habitats into viable HNV farming systems. The latter inevitably means addressing semi-natural habitats as social-ecological systems rather than purely as ecosystems. The studied region still only has a handful of interand transdisciplinary studies that bridge human and natural sciences, and indeed this line of research is non-existent in certain countries. Disciplinary research is also needed to address existing gaps in comparable data and to allow predictive modeling of community changes.

Responses to this article can be read online at: https://www.ecologyandsociety.org/issues/responses. php/12313 


\section{Acknowledgments:}

IH was supported by the HNV-Link project under the Horizon 2020 programme (project reference 696391), SW's input by the internal funding from NIBIO, KJR was funded by the Kone Foundation, Finland. SR was supported by the University of Latvia grant $\mathrm{Nr}$. AAP2016/B041//Zd2016/AZ03. We wish to thank Prof. Ove Eriksson for helpful suggestions. Open access funded by Helsinki University Library.

\section{Data Availability:}

The datalcode that support the findings of this study are openly available in Zenodo at http://doi.org/10.5281/zenodo.4016787.

\section{LITERATURE CITED}

Arponen, A., R. K. Heikkinen, R. Paloniemi, J. Pōyry, J. Similä, and M. Kuussaari. 2013. Improving conservation planning for semi-natural grasslands: integrating connectivity into agrienvironment schemes. Biological Conservation 160:234-241. https://doi.org/10.1016/j.biocon.2013.01.018

Artsdatabanken. 2018. Norsk rødliste for Naturtyper 2018. Artsdatabanken, Trondheim, Norway. [online] URL: https:// www.artsdatabanken.no/Pages/259099?Key=1521540851

Auffret, A. G., and S. A. O. Cousins. 2018. Land uplift creates important meadow habitat and a potential original niche for grassland species. Proceedings of the Royal Society B: Biological Sciences 285:20172349. https://doi.org/10.1098/rspb.2017.2349

Bele, B., L. Johansen, and A. Norderhaug. 2015. Resource use by old and modern dairy cattle breeds on semi-natural mountain pastures, Central Norway. Acta Agriculturae Scandinavica Section A-Animal Science 65(2):73-84. https://doi.org/10.1080/09064702.2015 .1070898

Bele, B., A. Norderhaug, and H. Sickel. 2018. Localized agri-food systems and biodiversity. Agriculture 8(2):22. https://doi. org/10.3390/agriculture8020022

Benedetti, Y. 2017. Trends in high nature value farmland studies: a systematic review. European Journal of Ecology 3(2):19-32. https://doi.org/10.1515/eje-2017-0012

Bengtsson J., J. M. Bullock, B. Egoh, C. Everson, T. Everson, T. O'Connor, P. J. O'Farrell, H. G. Smith, and R. Lindborg. 2019. Grasslands-more important for ecosystem services than you might think. Ecosphere 10(2):e02582. https://doi.org/10.1002/ $\underline{\text { ecs } 2.2582}$

Birge T., and I. Herzon 2014. Motivations and experiences in managing rare semi-natural biotopes: a case from Finland. Land Use Policy 41:128-37. https://doi.org/10.1016/j.landusepol.2014.05.004

Bommarco, R., R. Lindborg, L. Marini, and E. Öckinger. 2014. Extinction debt for plants and flower-visiting insects in landscapes with contrasting land use history. Diversity and Distributions 20 (5):591-599. https://doi.org/10.1111/ddi.12187

Bruchmann, I., and C. Hobohm. 2010. Halting the loss of biodiversity: endemic vascular plants in grasslands of Europe. Grassland Science in Europe 15:776-778.
Bullock, J. M., B. A. Woodcock, I. Herzon, and R. F. Pywell. 2020. Biodiversity in intensive grasslands: is a compromise possible? Grassland Science in Europe 25:384-393.

Cousins, S. A. O., A. G. Auffret, J. Lindgren, and L. Tränk. 2015. Regional-scale land-cover change during the 20th century and its consequences for biodiversity. Ambio 44(Supp11):S17-S27. https://doi.org/10.1007/s13280-014-0585-9

Cousins, S. A. O., and O. Eriksson. 2008. After the hotspots are gone: land use history and grassland plant species diversity in a strongly transformed agricultural landscape. Applied Vegetation Science 11(3):365-374. https://doi.org/10.3170/2008-7-18480

Cousins, S. A. O., and D. Vanhoenacker. 2011. Detection of extinction debt depends on scale and specialisation. Biological Conservation 144(2):782-787 https://doi.org/10.1016/j.biocon.2010.11.009

Daugstad, K., and C. Kirchengast. 2013. Authenticity and the pseudo-backstage of agri-tourism. Annals of Tourism Research 43:170-191. https://doi.org/10.1016/j.annals.2013.04.004

Daugstad, K., M. F. Mier, and L. Peña-Chocarro. 2014. Landscapes of transhumance in Norway and Spain: farmers' practices, perceptions, and value orientations. Norsk Geografisk Tidsskrift 68(4):248-258. https://doi.org/10.1080/00291951.2014.927395

Dengler, J., M., Janišová, P. Török, and C. Wellstein. 2014. Biodiversity of Palaearctic grasslands: a synthesis. Agriculture, Ecosystems and Environment 182:1-14. https://doi.org/10.1016/j. agee.2013.12.015

Dixon, A. P., D. Faber-Langendoen, C. Josse, J. Morrison, and C. J. Loucks. 2014. Distribution mapping of world grassland types. Journal of Biogeography 41:2003-2019. https://doi. org/10.1111/jbi.12381

Emanuelsson, U. 2009. The rural landscapes of Europe: how man has shaped European nature. The Swedish Research Council Formas, Varnamo, Sweden.

Eriksson O., and S. A. O. Cousins. 2014. Historical landscape perspectives on grasslands in Sweden and the Baltic Region. Land 3:300-321. https://doi.org/10.3390/land3010300

Eriksson O., S. A. O. Cousins, H. H. Bruun. 2002. Land use history and fragmentation of traditionally managed grasslands in Scandinavia. Journal of Vegetation Science 13(5):743-748. https://doi.org/10.1111/j.1654-1103.2002.tb02102.x

European Environment Agency (EEA). 2002. Europe's biodiversity - biogeographical regions and seas. EEA, Copenhagen, Denmark. [online] URL: https://www.eea.europa.eu/publications/ report 20020524154909

European Environment Agency (EEA). 2016. Mapping and assessing the condition of Europe's ecosystems: progress and challenges. EEA contribution to the implementation of the EU Biodiversity Strategy to 2020. EEA Report No 3/2016. EEA, Copenhagen, Denmark. [online] URL: https://www.eea.europa. eu/publications/mapping-europes-ecosystems

European Union (EU). 2013. Regulation (EU) No 1307/2013 of the European Parliament and of the Council of 17 December 2013. Official Journal of the European Union 347/608. EU, 
Brussels, Belgium. [online] URL: https://publications.europa.eu/ en/publication-detail/-/publication/69850116-6c04-11e3-9afb-01aa75ed71a1/language-en

EUROSTAT. 2013. Share of different land uses in permanent grassland and meadow, EU-28 and Norway, 2013. European Commission, Brussels, Belgium. [online] URL: https://ec.europa. eu/eurostat/statistics-explained/index.php?title=File:

Share of different land uses in permanent grassland and meadow. EU-28 and Norway, 2013.png\&oldid $=332230$

EUROSTAT. 2015. Agri-environmental indicator - cropping patterns. In focus: arable land and fodder areas. European Commission, Brussels, Belgium. [online] URL: https://ec.europa. eu/eurostat/statistics-explained/index.php/Agri-environmental indicator cropping patterns\#In focus: arable land and fodder areas

Fischer, J., T. Hartel, and T. Kuemmerle. 2012. Conservation policy in traditional farming landscapes. Conservation Letters 5:167-175. https://doi.org/10.1111/j.1755-263X.2012.00227.x

García-Feced, C., C. J. Weissteiner, A. Baraldi, M. L. Paracchini, J. Maes, G. Zulian, M. Kempen, B. Elbersen, and M. Pérez-Soba. 2015. Semi-natural vegetation in agricultural land: European map and links to ecosystem service supply. Agronomy for Sustainable Development 35(1):273-283. https://doi.org/10.1007//13593-014-0238-1

Halada, L., D. Evans, C. Romão, and J.-E. Petersen. 2011. Which habitats of European importance depend on agricultural practices? Biodiversity Conservation 20:2365-2378. https://doi. org/10.1007/s10531-011-9989-Z

Hansen, H. S., U.-B. Bøe, and H. Okkenhaug. 2009. Herbage production and live weight gain in dairy heifers grazing forest habitats in Norway. Acta Agriculturae Scandinavica A: Animal Sciences 59(3):161-166. https://doi.org/10.1080/09064700903302858

Hartel, T., and T. Plieninger, editors. 2014. European woodpastures in transition: a social-ecological approach. Routledge, New York, New York, USA. https://doi.org/10.4324/9780203797082

Heinsoo, K., I. Melts, M. Sammul, and B. Holm. 2010. The potential of Estonian semi-natural grasslands for bioenergy production. Agriculture Ecosystems and Environment 137:86-92. https://doi.org/10.1016/j.agee.2010.01.003

Helm, A., I. Hanski, and M. Pärtel. 2006. Slow response of plant species richness to habitat loss and fragmentation. Ecology Letters 9:72-77. https://doi.org/10.1111/j.1461-0248.2005.00841.x

Hensgen, F., L. Bühle, and M. Wachendorf. 2016. The effect of harvest, mulching and low-dose fertilization of liquid digestate on above ground biomass yield and diversity of lower mountain semi-natural grasslands. Agriculture Ecosystems and Environment 216:283-292. https://doi.org/10.1016/j.agee.2015.10.009

Herzon, I., T. Birge, B. Allen, A. Povellato, F. Vanni, K. Hart, G. Radley, G. Tucker, C. Keenleyside, R. Oppermann, E. Underwood, X. Poux, G. Beaufoy, and J. Pražan. 2018. Time to look for evidence: results-based approach to biodiversity conservation on farmland in Europe. Land Use Policy 71:347-354. https://doi.org/10.1016/j.landusepol.2017.12.011

Hopkins, A. 2009. Relevance and functionality of semi-natural grassland in Europe: status quo and future prospective. Pages 9-14 in International Workshop of the SALVERE-Project, 26-27 May 2009. Agricultural Research and Education Centre, RaumbergGumpenstein, Austria.

Jakobsson, A., and J. Ågren. 2014. Distance to semi-natural grassland influences seed production of insect-pollinated herbs. Oecologia 175(1):199-208. https://doi.org/10.1007/s00442-014-2904$\underline{\mathrm{z}}$

Janssen, J. A. M., J. S. Rodwell, M. García Criado, S. Gubbay, T. Haynes, A. Nieto, N. Sanders, F. Landucci, J. Loidi, A. Ssymank, T. Tahvanainen, M. Valderrabano, A. Acosta, M. Aronsson, G. Arts, F. Attorre, E. Bergmeier, R.-J. Bijlsma, F. Bioret, C. BiţăNicolae, I. Biurrun, M. Calix, J. Capelo, A. Čarni, M. Chytrý, J. Dengler, P. Dimopoulos, F. Essl, H. Gardfjell, D. Gigante, G. Giusso del Galdo, M. Hájek, F. Jansen, J. Jansen, J. Kapfer, A. Mickolajczak, J. A. Molina, Z. Molnár, D. Paternoster, A. Piernik, B. Poulin, B. Renaux, J. H. J. Schaminée, K. Šumberová, H. Toivonen, T. Tonteri, I. Tsiripidis, R. Tzonev, and M. Valachovič. 2016. European Red List of Habitats. Part 2. Terrestrial and freshwater habitats. European Union, Brussels, Belgium.

Johansen, L., S. Wehn, K. Hovstad, and L. G. Velle. 2015. Kystlynghei i Naturindeks for Norge-Utvikling av indikatorer og datagrunnlag. [Coastal grasslands in the Nature Index for Norway - Development of indicators and data bases.] NIBIO Rapport, Ås, Norway.

Kalda, J. 2017. Semi-natural habitats caregivers attitudes and influence factors on maintenance on the example of Voru county. Thesis. Estonian University of Life Sciences, Tartu, Estonia. [online] URL: https://dspace.emu.ee/xmlui/bitstream/handle/10492/3330/ $\underline{\text { Janne Kalda MA2017.pdf? sequence }=3}$

Keenleyside, C., G. Beaufoy, G. Tucker, and G. Jones. 2014. High nature value farming throughout EU-27 and its financial support under the CAP. Institute for European Environmental Policy, London, UK.

Kimberley, A., J. M. Bullock, and S. A. O. Cousins. 2019. Unbalanced species losses and gains lead to non-linear trajectories as grasslands become forests. Journal of Vegetation Science 30:1089-1098. https://doi.org/10.1111/jvs.12812

Kumm, K.-I. 2003. Sustainable management of Swedish seminatural pastures with high species diversity. Journal Nature Conservation 11:117-125. https://doi.org/10.1078/1617-1381-00039

Kumm, K.-I. 2004. Does re-creation of extensive pasture-forest mosaics provide an economically sustainable way of nature conservation in Sweden's forest dominated regions? Journal Nature Conservation 12:213-218. $\underline{\text { https://doi.org/10.1016/j. }}$ inc.2004.07.001

Kvakkestad, V., P. K. Rørstad, and A. Vatn. 2015. Norwegian farmers' perspectives on agriculture and agricultural payments: between productivism and cultural landscapes. Land Use Policy 42:83-92. https://doi.org/10.1016/j.landusepol.2014.07.009

Lennartsson, T., O. Eriksson, A. Iuga, J. Larsson, J. Moen, M. Scholl, A. Westin, and C. Crumley. 2018. Diversity in ecological and social contexts. Pages 182-239 in C. Crumley, T. Lennartsson, and A. Westin, editors. Issues and concepts in historical ecology: the past and future of landscapes and regions. Cambridge 
University Press, Cambridge, UK. https://doi.org/10.1017/9781108355780.007

Liechti, K., and J.-P. Biber. 2016. Pastoralism in Europe: characteristics and challenges of highland-lowland transhumance. Revue scientifique et technique (International office of Epizootics) 35:561-575. https://doi.org/10.20506/rst.35.2.2541

Lindborg, R., J. Bengtsson, Å. Berg, S. A. O. Cousins, O. Eriksson, T. Gustafsson, K. P. Hasund, L. Lenoir, A. Pihlgren, E. Sjödin, and M. Stenseke. 2008. A landscape perspective on conservation of semi-natural grasslands. Agriculture, Ecosystems and Environment 125:213-222. https://doi.org/10.1016/j.agee.2008.01.006

Lomba, A., C. Guerra, J. Alonso, J. P. Honrado, R. Jongman, and D. McCracken. 2014. Mapping and monitoring high nature value farmlands: challenges in European landscapes. Journal of Environmental Management 143:140-150. https://doi.org/10.1016/ j.jenvman.2014.04.029

Lomba, A., F. Moreira, S. Klimek, R. Jongman, C. Sullivan, J. Moran, X. Poux, J. P. Honrado, T. Pinto-Correia, T. Plieninger, and D. I. McCracken. 2019. Back to the future: rethinking the socioecological systems underlying high nature value farmlands. Frontiers in Ecology and the Environment 18(1):36-42. https://doi. $\underline{\text { org/10.1002/fee. } 2116}$

Lundgren, R., Ø. Totland, and A. Lázaro. 2016. Experimental simulation of pollinator decline causes community-wide reductions in seedling diversity and abundance. Ecology 97 (6):1420-1430. https://doi.org/10.1890/15-0787.1

Luoto, M., S. Rekolainen, J. Aakkula, and J. Pykälä. 2003. Loss of plant species richness and habitat connectivity in grasslands associated with agricultural change in Finland. $A M B I O$ 32:447-452. https://doi.org/10.1579/0044-7447-32.7.447

Mabille, G., A. Stien, T. Tveraa, A. Mysterud, H. Brøseth, and J. D. C. Linnell. 2015. Sheep farming and large carnivores: What are the factors influencing claimed losses? Ecosphere 6(5):1-17. https://doi.org/10.1890/ES14-00444.1

Melts, I., K. Heinsoo, and M. Ivask. 2014. Herbage production and chemical characteristics for bioenergy production by plant functional groups from semi-natural grasslands. Biomass and Bioenergy 67:160-166. https://doi.org/10.1016/j.biombioe.2014.04.037

Ministry of Agriculture. 1999. St. meld. nr 19 (1999-2000): Om norsk landbruk og matproduksjon. Ministry of Agriculture, Oslo, Norway.

Ministry of the Environment. 2009. Act of 19 June 2009 No. 100 Relating to the Management of Biological, Geological and Landscape Diversity (Nature Diversity Act). Ministry of the Environment, Oslo, Norway.

Moen, A., A. Lyngstad, and D. I. Øien. 2015. Hay crop of boreal rich fen communities traditionally used for haymaking. Folia Geobotanica 50:25-38. https://doi.org/10.1007/s12224-015-9204-1

Mussaari, M., N. Käyhkö, G. Haggrén, H. Jansson, L. Lindgren, T. Pitkänen, and K. Raatikainen. 2012. Management guidelines for semi-natural landscapes — integrating historical perspectives and GIS into planning process. University of Turku, Turku, Finland.
Newbold, T., L. N. Hudson, A. P. Arnell, S. Contu, A. De Palma, S. Ferrier, S. L. L. Hill, A. J. Hoskins, I. Lysenko, H. R. P. Phillips, V. J. Burton, C. W. T. Chng, S. Emerson, D. Gao, G. Pask-Hale, J. Hutton, M. Jung, K. Sanchez-Ortiz, B. I. Simmons, S. Whitmee, H. Zhang, J. P. W. Scharlemann, and A. Purvis. 2016. Has land use pushed terrestrial biodiversity beyond the planetary boundary? A global assessment. Science 353:288-291. https://doi. org/10.1126/science.aaf2201

Norderhaug, A., and L. Johansen. 2011. Semi-natural sites and boreal heaths. Pages 87-93 in A. Lindgaard and S. Henriksen, editors. The 2011 Norwegian Red List for ecosystems and habitat types. Norwegian Biodiversity Information Centre, Trondheim, Norway.

Norwegian Environment Agency. 2009. Handlingsplan for slåttemark [Action plan for hay meadows]. DN-rapport 6-2009. Norwegian Environment Agency, Oslo, Norway.

Öckinger, E., and H. G. Smith. 2007. Semi-natural grasslands as population sources for pollinating insects in agricultural landscapes. Journal of Applied Ecology 44(1):50-59. https://doi. org/10.1111/j.1365-2664.2006.01250.x

Ödman, A. M., and P. A. Olsson. 2014. Conservation of sandy calcareous grassland: What can be learned from the land use history? PLoS ONE 9(3):e90998. https://doi.org/10.1371/journal. pone.0090998

Olsson, E. G. A., G. Austrheim, and S. N. Grenne. 2000. Landscape change patterns in mountains, land use and environmental diversity, Mid-Norway 1960-1993. Landscape Ecology 15:155-170. https://doi.org/10.1023/A:1008173628016

Olsson, E. G. A., K. Rönningen, S. K. Hanssen, and S. Wehn. 2011. The interrelationship of biodiversity and rural viability: sustainability assessment, land use scenarios and Norwegian mountains in a European context. Journal of Environmental Assessment Policy and Management 13:251-284. https://doi. org/10.1142/S1464333211003870

Pärtel, M., R. Mändla, and M. Zobel. 1999. Landscape history of a calcareous (alvar) grassland in Hanila, western Estonia, during the last three hundred years. Landscape Ecology 14 (2):187-196. https://doi.org/10.1023/a:1008040114832

Peeters, A. 2015. Environmental impacts and future challenges of grasslands and grassland based livestock production systems in Europe. Pages 365-390 in P. K. Ghosh, S. K. Mahanta, J. B. Singh, and P. S. Pathak, editors. A global resource perspective edition: International Grassland Congress and Range Management Society of India. Army Printing Press, Lucknow, India.

Peeters, A. I., G. Beaufoy, R. M. Canals, A. De Vliegher, C. Huyghe, J. Isselstein, G. Jones, W. Kessler, A. Kirilov, M. R. Mosquera-Losada, N. Nilsdotter-Linde, G. Parente, J.-L. Peyraud, J. Pickert, S. Plantureux, C. Porqueddu, D. Rataj, P. Stypinski, B. Tonn, A. van den Pol-van Dasselaar, V. Vintu, and R. J. Wilkins. 2014. Grassland term definitions and classifications adapted to the diversity of European grassland-based systems. Pages 743-750 in A Hopkins, R. P. Collins, M. D. Fraser, V. R. King, D. C. Lloyd, J. M. Moorby, and P. R. H. Robson, editors. EGF at 50: the future of European grasslands: Proceedings of the 25th General Meeting of the European Grassland Federation, Aberystwyth, Wales, 7-11 September 2014. Volume 19. 
Organising Committee of the 25th General Meeting of the European Grassland Federation IBERS, Aberystwyth University, Gogerddan, UK.

Plieninger, T., T. Hartel, B. Martín-López, G. Beaufoy, E. Bergmeier, K. Kirby, M. J. Montero, G. Moreno, E. Oteros-Rozas, and J. Van Uytvancki. 2015. Wood-pastures of Europe: geographic coverage, social-ecological values, conservation management, and policy implications. Biological Conservation 190:70-79. https://doi.org/10.1016/j.biocon.2015.05.014

Plue, J., T. Aavik, and S. A. O. Cousins. 2019. Grazing networks promote plant functional connectivity among isolated grassland communities. Diversity and Distributions 25:102-115. https://doi. org/10.1111/ddi.12842

Raatikainen, K. J., and E. S. Barron. 2017. Current agrienvironmental policies dismiss varied perceptions and discourses on management of traditional rural biotopes. Land Use Policy 69:564-576. https://doi.org/10.1016/j.landusepol.2017.10.004

Raatikainen, K. J., M. Mussaari, K. M. Raatikainen, and P. Halme. 2017. Systematic targeting of management actions as a tool to enhance conservation of traditional rural biotopes. Biological Conservation 207:90-99. https://doi.org/10.1016/j. biocon.2017.01.019

Rosef, L., and H. Bonesmo. 2005. Seasonal variation in productivity in semi-natural grasslands. Acta Agriculturae Scandinavica Section B-Soil and Plant Science 55:36-43. https:// doi.org/10.1080/09064710510008630

Rūsina, S., editor. 2017. Outstanding semi-natural grassland sites in Latvia: biodiversity, management, restoration. University of Latvia, Riga, Latvia.

Saastamoinen, M., I. Herzon, S. Sarkijarvi, C. Schreurs, and M. Myllymaki. 2017. Horse welfare and natural values on seminatural and extensive pastures in Finland: synergies and tradeoffs. Land 6(4)69. https://doi.org/10.3390/land6040069

Skuodiene, R., K. Katutis, R. Nekrosiene, R. Repsiene, and D. Karcauskiene. 2016. Effects of soil properties and humidity regimes on semi-natural meadow productivity. Acta Agriculturae Scandinavica Section B-Soil \& Plant Science 66(8):653-663. https://doi.org/10.1080/09064710.2016.1197966

Slepetiene, A., I. Liaudanskiene, J. Slepetys, V. Stukonis, I. Jokubauskaite, and J. Ceseviciene. 2013. Comparison of soil organic matter content and composition in protected areas of NATURA 2000 and agrarian lands. Journal of Food, Agriculture and Environment 11(2):1105-1110.

Squires, V. R., J. Dengler, L. Hua, and F. Feng, editors. 2017. Grasslands of the world: diversity, management and conservation. First edition. CRC Press, Boca Raton, Florida, USA. https://doi. org/10.1201/9781315156125

Stenseke, M. 2006. Biodiversity and the local context: linking seminatural grasslands and their future use to social aspects. Environmental Science and Policy 9:350-359. https://doi. org/10.1016/j.envsci.2006.01.007

Sutcliffe, L. M. E., P. Batáry, U. Kormann, A. Báldi, L. V. Dicks, I. Herzon, D. Kleijn, P. Tryjanowski, I. Apostolova, R. Arlettaz, A. Aunins, S. Aviron, L. Balezentiene, C. Fischer, L. Halada, T.
Hartel, A. Helm, I. Hristov, S. V. Jelaska, M. Kaligarič, J. Kamp, S. Klimek, P. Koorberg, J. Kostiuková, A. Kovács-Hostyánszki, T. Kuemmerle, C. Leuschner, R. Lindborg, J. Loos, S. Maccherini, R. Marja, O. Máthé, I. Paulini, V. Proença, J. Rey-Benayas, F. X. Sans, C. Seifert, J. Stalenga, J. Timaeus, P. Török, C. van Swaay, E. Viik, and T. Tscharntke. 2015. Harnessing the biodiversity value of Central and Eastern European farmland. Diversity and Distributions 21:722-730. https://doi.org/10.1111/ddi.12288

Svensson, E. 2018. The Scandinavian shieling - between innovation and tradition. Pages 15-27 in E. Costello and E. Svensson, editors. Historical archaeologies of transhumance across Europe. Routledge, London, UK. https://doi.org/10.4324/9781351213394-2

Swensen, G. 2008. Rural tourism and processes of cultural heritage manufacture. Sustainable Tourism III 115:295-304. https://doi.org/10.2495/ST080291

Takkis, K., M. Pártel, L. Saar, and A. Helm. 2013. Extinction debt in a common grassland species: immediate and delayed responses of plant and population fitness. Plant Ecology 214:953-963. https://doi.org/10.1007/s11258-013-0221-y

Tiainen, J., T. Hyvönen, M. Hagner, E. Huusela-Veistola, P. Louhi, A. Miettinen, T. Nieminen, A. Palojärvi, T. Seimola, P. Taimisto, and P. Virkajärvi. 2020. Biodiversity in intensive and extensive grasslands in Finland: the impacts of spatial and temporal changes of agricultural land use. Agricultural and Food Science 29:68-97. https://doi.org/10.23986/afsci.86811

Török, P., M. Janišová, A. Kuzemko, S. Rūsina and Z. Dajić Stevanović. 2018. Grasslands, their threats and management in Eastern Europe. Pages 64-88 in V. R. Squires, J. Dengler, H. Feng, and L. Hua, editors. Grasslands of the world: diversity, management and conservation. CRC Press, Boca Raton, Florida, USA. https://doi.org/10.1201/9781315156125

Torralba, M., N. Fagerholm, T. Hartel, G. Moreno, and T. Plieninger. 2018. A social-ecological analysis of ecosystem services supply and trade-offs in European wood-pastures. Science Advances 4(5):eaar2176. https://doi.org/10.1126/sciadv. $\underline{\operatorname{aar} 2176}$

Veen, P., R. Jefferson, J. de Smidt, and J. van der Straaten. 2009. Grasslands in Europe of high nature value. KKNV Publishing, Den Haag, The Netherlands. https://doi.org/10.1163/9789004278103

Villa, M., and K. Daugstad. 2007. Summer farmers: gender discourses in new arenas. 2007. Journal of Comparative Family Studies 38(3):395-408. https://doi.org/10.3138/jcfs.38.3.395

Villoslada, M., I. Vinogradovs, A. Ruskule, K. Veidemane, O. Nikodemus, R. Kasparinskis, K. Sepp, and J. Gulbinas. 2018. A multitiered approach for grassland ecosystem services mapping and assessment: the Viva Grass tool. One Ecosystem 3:e25380. https://doi.org/10.3897/oneeco.3.e25380

Vinogradovs, I., O. Nikodemus, D. Elferts, and G. Brūmelis. 2018. Assessment of site-specific drivers of farmland abandonment in mosaic-type landscapes: a case study in Vidzeme, Latvia. Agriculture, Ecosystems and Environment 253:113-121. https:// doi.org/10.1016/j.agee.2017.10.016

Virret, E. T., K. J. Raatikainen, N. Fagerholm, N. Käyhkö, and P. Vihervaara. 2019. Ecosystem services at the Archipelago Sea 
Biosphere Reserve in Finland: a visitor prspective. Sustainability 11(2):421. https://doi.org/10.3390/su11020421

Vuorisalo, T., and P. Laihonen. 2000. Biodiversity conservation in the north: history of habitat and species protection in Finland. Annales Zoologici Fennici 37:281-297.

Wehn, S., R. Burton, M. Riley, L. Johansen, K. A. Hovstad, and K. Rønningen. 2018b. Adaptive biodiversity management of semi-natural hay meadows: the case of West-Norway. Land Use Policy 72:259-269. https://doi.org/10.1016/j.landusepol.2017.12.063

Wehn, S., K. A. Hovstad, and L. Johansen. 2018a. The relationships between biodiversity and ecosystem services and the effects of grazing cessation in semi-natural grasslands. Web Ecology 18(1):55-65. https://doi.org/10.5194/we-18-55-2018

White, R., S. Murray, and M. Rohweder. 2000. Pilot analysis of global ecosystems: grassland ecosystems. World Resources Institute, Washington, D.C., USA. [online] URL: http://www.wri. org/wr2000.

Wilson, J. B., R. K. Peet, J. Dengler, and M. Pärtel. 2012. Plant species richness: the world records. Journal for Vegetation Science 23(4):796-802. https://doi.org/10.1111/j.1654-1103.2012.01400.x 


\section{Appendix 1}

\section{Table A1.1.}

Areas of the main grassland types, in thousands of hectares, their percentages of the total grassland use, and percentage of the total grassland use of the Utilised Agricultural Area in the countries of the boreal region. The data are derived from the respective national Statistical Bureaus on land use for 2017/2018 and for 2010 for Norway (comparable data). For the semi-natural grasslands, the estimates are based on the most recent national expert assessments. Only areas that are subsidised and managed either for production or as part of agricultural policy requirements are included.

\begin{tabular}{|c|c|c|c|c|c|c|c|c|c|c|c|c|}
\hline $\begin{array}{r}\text { Grassland } \\
\text { type }\end{array}$ & \multicolumn{2}{|c|}{ Estonia $^{1}$} & \multicolumn{2}{|c|}{ Finland $^{2}$} & \multicolumn{2}{|r|}{ Latvia $^{3}$} & \multicolumn{2}{|c|}{ Lithuania $^{4}$} & \multicolumn{2}{|c|}{ Norway $^{5}$} & \multicolumn{2}{|c|}{ Sweden } \\
\hline $\begin{array}{r}\text { Temporary } \\
\text { grassland }\end{array}$ & 108 & $27 \%$ & 727 & $97 \%$ & 174 & $26 \%$ & 153 & $17 \%$ & 279 & $42 \%$ & 1100 & $71 \%$ \\
\hline $\begin{array}{r}\text { Permanent } \\
\text { grassland, } \\
\text { excluding } \\
\text { semi-natural } \\
\text { grassland }^{7}\end{array}$ & 251 & $64 \%$ & 4 & $3 \%$ & 469 & $69 \%$ & 696 & $77 \%$ & 337 & $50 \%$ & 140 & $9 \%$ \\
\hline $\begin{array}{r}\text { Semi-natural } \\
\text { grassland }\end{array}$ & 34 & $9 \%$ & 20 & $1 \%$ & 37 & $5 \%$ & 51 & $6 \%$ & 53 & $8 \%$ & 313 & $20 \%$ \\
\hline $\begin{array}{r}\text { Total } \\
\text { grassland }\end{array}$ & 393 & $39 \%$ & 751 & $33 \%$ & 680 & $39 \%$ & 900 & $31 \%$ & 669 & $68 \%$ & 1552 & $51 \%$ \\
\hline $\begin{array}{r}\text { Utilised } \\
\text { Agricultural } \\
\text { Area }\end{array}$ & 1000 & & 2258 & & 1722 & & 2882 & & 987 & & 3021 & \\
\hline
\end{tabular}

'Estonian Statistics 2017. https://www.stat.ee/34226; Helm, A., Toussaint, A. 2020. Poollooduslike koosluste ökoloogilise toimimise hinnang. Tartu Ülikool, Ökoloogia ja Maateaduste Instituut. https://www.envir.ee/sites/default/files/poollooduslike_koosluste_okoloogilise_toimimise hinnang_03_2020_tartu_ul. .pdf

2 Source: Natural Resources Institute Finland, Utilized agricultural area 2017. https://stat.luke.fi/; Lehtomaa et al. 2018. Threatened habitat types in Finland 2018: Red List of habitats.

${ }^{3}$ Rural Support Service 2018. [Approved areas by crop code and type of support in 2018] Available from http://www.lad.gov.lv/files/apstiprinatas_platibas_pa_kulturam_un_atbalsta_veidiem_2018_gada_uz_26_03_2019.xlsx ${ }^{4}$ State Enterprise Agricultural Information and Rural Business Centre 2018. [Utilization of agricultural land] https://www.vic.lt/ppis/statistika/

${ }_{5}^{5}$ SSB Statistics Norway https://www.ssb.no/jord-skog-jakt-og-fiskeri/statistikker/stjord; Naturbase (produced by the Norwegian environmental agency) https://www.miljodirektoratet.no/verktoy/naturbase/, and Eurostat 2010 https://ec.europa.eu/eurostat/statistics-explained/index.php?oldid=249311\#Land use (Table 4)

${ }^{6}$ Statistics Sweden, Agricultural statistics 2018. urn:nbn:se:scb-2018-jo02br1801_pdf. Available from https://www.scb.se/en/; Grassland reporting group to the EU, article 17 [the figure includes coastal and alvar grasslands]. Available from https://cdr.eionet.europa.eu/se/eu/art17/envxmgsnw/

${ }^{7}$ The reported permanent grassland areas reduced by the best available national estimates for semi-natural grassland areas under subsidised management 